Eur. J. Clin. Chem. Clin. Biochem.

Vol. 30, 1992, pp. $349-355$

(C) 1992 Walter de Gruyter \& Co. Berlin $\cdot$ New York

\title{
Stability of Blood Gases, Electrolytes and Haemoglobin in Heparinized Whole Blood Samples: Influence of the Type of Syringe
}

\author{
By $O$. Müller-Plathe and S. Heyduck*) \\ Zentrallaboratorium des Allgemeinen Krankenhauses Altona, Hamburg, Germany
}

(Received December 15, 1991/April 1, 1992)

Summary: The alterations of blood gases, $\mathrm{pH}$, electrolytes and haemoglobin during 45 min storage in icewater were measured in 6 types of syringes ( 1 glass and 5 plastic syringes, among these 3 "blood gas samplers"). It was confirmed that $p \mathrm{O}_{2}$ generally is not stable in plastic syringes. However, considerable differences among plastic syringes were found in this respect, the smallest increase occuring in an ordinary $2 \mathrm{ml}$ syringe for injections and the greatest in one of the special blood gas samplers. Due to the "buffering effect" of deoxyhaemoglobin, the alterations of $p \mathrm{O}_{2}$ are smaller in the hypoxaemic than in the normoxaemic range. Relevant $\mathrm{pO}_{2}$ alterations in plastic syringes are demonstrable after 20 minutes. It is concluded that blood collected in plastic syringes must be analysed within $15 \mathrm{~min}$ after sampling, otherwise glass syringes should be used for blood collection.

Deviations of $p \mathrm{CO}_{2}, \mathrm{pH}$ and electrolytes are described in detail. In general, they are due to sampling rather than to storage, and can be effectively minimized by a small dead space of the syringe and by use of an electrolyte-balanced heparin solution. The danger of erroneous haemoglobin measurements due to unequal resuspension of the red cells after storage is pointed out.

\section{Introduction}

Simultaneous measurement of $\mathrm{pH}$, blood gases, electrolytes and haemoglobin (or haematocrit) in a heparinized whole blood sample is becoming increasingly accepted. To obtain reliable results, several preanalytical requirements must be fulfilled:

1. The syringe should allow bubble-free sampling. This is mainly influenced by the construction of the syringe.

2. The syringe should be as gas-tight as possible. Tightness is influenced by the material (glass or plastic), by the volume-to-surface ratio and by the construction (e.g. fitting of the plunger).

*) The findings published in the present paper are part of the dissertation of St. Heyduck "Stabilität von Blutgasparametern, Elektrolyt- und Hämoglobinkonzentration in verschiedenen Spritzentypen“, Hamburg, University, 1991.
3. The anticoagulant should not alter the concentration of blood components to a relevant extent. Alterations may be caused by

- dilution, if liquid heparin preparations are used.

- contamination, if a heparin solution without electrolyte balance is used.

- binding processes (mainly applying to calcium), if too much heparin without "calcium titration" is used.

4. The blood cells should be easily resuspendable in order to obtain reproducible haemoglobin or haematocrit values. This depends on the construction (metal flea or platelet) and on the volume-to-surface ratio. 
We examined 6 types of syringes with regard to alterations of the components mentioned during $45 \mathrm{~min}$ storage. Additionally, the time course of alterations of $p \mathrm{O}_{2}$ in glass and plastic syringes was investigated.

\section{Materials and Methods}

The syringes tested are described in table 1. SA, TE and RA are commercial blood gas syringes with a dry heparin preparation. To fill the dead space and to lubricate the plunger of GL, B1 and B2, Vetren 200 ${ }^{\circledR}$ (Promonta, Hamburg, Germany) was used which has an electrolyte balanced composition according to 1 .c. (1). The glass syringe was provided with a metal platelet for mixing. Cannulas $(0.80 \times 60 \mathrm{~mm})$ were used for aspiration.

Heparinized blood was equilibrated according to the IFCC method (2), using the thin-film-tonometer IL 237 (Instrumentation Laboratory) and the following gas mixtures.
A. $0.1235 \mathrm{l} / 1 \mathrm{O}_{2}, 0.0518 \mathrm{l} / \mathrm{COO}_{2}, 0.8247 \mathrm{l} / 1 \mathrm{~N}_{2}$ (series I)
B. $0.1200 \mathrm{l} / 1 \mathrm{O}_{2}, 0.0500 \mathrm{l} / 1 \mathrm{CO}_{2}, 0.8300 \mathrm{l} / 1 \mathrm{~N}_{2}$ (series III and IV)
C. $0.0743 \mathrm{l} / 1 \mathrm{O}_{2}, 0.0664 \mathrm{l} / 1 \mathrm{CO}_{2}, 0.8593 \mathrm{l} / 1 \mathrm{~N}_{2}$ (series II)

Measurements were done with a Corning 288 blood gas analyser $\left(\mathrm{pH}, p \mathrm{CO}_{2}, p \mathrm{O}\right.$, concentrations of $\mathrm{Na}^{+}, \mathrm{K}^{+}, \mathrm{Ca}^{2+}$ by electrodes and $\mathrm{Hb}$ concentration by photometry) in series $\mathrm{I}$ and with a Corning $178\left(\mathrm{pH}, p \mathrm{CO}_{2}, p \mathrm{O}_{2}\right)$ in series II, III and IV. For quality control, Euro-Trol D (Euro-Trol. Wakeningen, The Netherlands) was analysed with the Corning 288, and Confirm (Ciba-Corning) was analysed with the Corning 178; in each case the analysis was performed daily at 3 levels.

\section{Series of experiments}

\section{Series I and II}

Pooled heparinized blood $(9 \mathrm{ml})$ was equilibrated in the IL 237 tonometer. After $20 \mathrm{~min}$ blood was aspirated into the first of the 6 syringes, air bubbles were removed if necessary, the sample was analysed immediately and thereafter stored in ice-water. Then the next syringe was treated in the same manner, and so forth. The sequence of the syringes was changed in each set. $45 \pm 5 \mathrm{~min}$ after the first measurement the syringes were removed from the ice-water, mixed carefully by inversion five times and by rolling between the palms ten seconds and measured again.

Series I consisted of 34 sets of 6 samples, measured with a Corning 288 after equilibration with gas mixture A. Series II consisted of 25 sets of 6 samples, measured with a Corning 178 after equilibration with gas mixture $C$ (the results are shown in fig. 1-4).

\section{Series III}

Series III consisted of 25 pairs of a glass syringe (GL) and a $1 \mathrm{ml}$-plastic syringe (B1). The blood was equilibrated with gas mixture $B$ and measured with a Corning 178 immediately after sampling and after 10 and $20 \mathrm{~min}$ storage in ice-water (results see fig. 5).

\section{Series IV}

Heparinized whole blood and plasma, prepared by centrifugation from the same blood sample, were equilibrated with gas mixture $B$ as described before $(n=15)$. Both specimens were aspirated into a glass (GL) and a plastic syringe (B1). $\mathrm{pO}_{2}$ in blood and plasma was measured with a Corning 178 immediately after aspiration and after 10,20 and 45 min storage at room temperature (results see fig. $6 a-b$ ).

Tab. 1. Explanations and specifications of the syringes examined.

\begin{tabular}{|c|c|c|c|c|c|c|}
\hline \multirow[b]{2}{*}{$\begin{array}{l}\text { Symbol in the } \\
\text { present paper }\end{array}$} & \multirow{2}{*}{$\begin{array}{l}\text { Injection } \\
\text { syringe } \\
\text { (glass) }\end{array}$} & \multicolumn{3}{|c|}{$\begin{array}{l}\text { Commercial "Blood gas samplers" } \\
\text { (plastic material) }\end{array}$} & \multicolumn{2}{|c|}{$\begin{array}{l}\text { Injection syringes } \\
\text { (plastic material) }\end{array}$} \\
\hline & & SA & $\mathrm{TE}$ & $\mathrm{RA}$ & B2 & $\mathrm{B} 1$ \\
\hline Manufacturer & Graf & Sarstedt & Terumo & Radiometer & Braun & Braun \\
\hline Type & Fortuna & $\begin{array}{l}\text { Monovette } \\
\text { LH }\end{array}$ & $\begin{array}{l}\text { Preza-Pak } \\
\text { II }\end{array}$ & $\begin{array}{l}\text { Art. samp. } \\
\text { B } 129\end{array}$ & Inject & Omnifix \\
\hline Material & Glass & $\begin{array}{l}\text { Polypro- } \\
\text { pylene }\end{array}$ & $\begin{array}{l}\text { Polypro- } \\
\text { pylene }\end{array}$ & $\begin{array}{l}\text { Polypro- } \\
\text { pylene }\end{array}$ & $\begin{array}{l}\text { Polypro- } \\
\text { pylene }\end{array}$ & $\begin{array}{l}\text { Polypro- } \\
\text { pylene }\end{array}$ \\
\hline $\begin{array}{l}\text { Nominal } \\
\text { volume (ml) }\end{array}$ & 5.0 & 2.0 & 2.5 & 1.0 & 2.0 & 1.0 \\
\hline \multirow{2}{*}{$\begin{array}{l}\text { Kind of } \\
\text { heparin }\end{array}$} & $\mathrm{Na}$ salt & Li salt & Li salt & $\begin{array}{l}\mathrm{Na} \text { and } \mathrm{Li} \\
\text { salts }\end{array}$ & $\mathrm{Na}$ salt & $\mathrm{Na}$ salt \\
\hline & $\begin{array}{l}\text { Fluid* } \\
\text { Electro- } \\
\text { lyte- } \\
\text { blanced }\end{array}$ & Dry & Dry & $\begin{array}{l}\text { Dry } \\
\text { Electro- } \\
\text { lyte- } \\
\text { balanced }\end{array}$ & $\begin{array}{l}\text { Fluid* } \\
\text { Electro- } \\
\text { lyte- } \\
\text { balanced }\end{array}$ & $\begin{array}{l}\text { Fluid* } \\
\text { Electro- } \\
\text { lyte- } \\
\text { balanced }\end{array}$ \\
\hline $\begin{array}{l}\text { Concentration } \\
\text { of heparin } \\
\left(10^{3} \text { IU per litre }\right. \\
\text { blood })\end{array}$ & 10 & 15 & 50 & 70 & 5 & 5 \\
\hline
\end{tabular}

\footnotetext{
* Vetren $200^{\circledR}$ (Promonta, Hamburg, Germany)
} 


\section{Results}

\section{Series I and II}

$p \mathrm{O}_{2}$

It can be seen from figure 1 that the glass syringe is clearly superior to all plastic syringes. At the normal level (left) all plastic syringes showed a remarkable increase in $\mathrm{pO}_{2}$ after $45 \mathrm{~min}$ storage, which was greatest in the Sarstedt (SA) and the Braun 1-ml syringe (about $0.8 \pm 0.4 \mathrm{kPa} ; 6 \pm 3 \mathrm{~mm} \mathrm{Hg}$ ) and smallest in the Braun 2-ml syringe (about $0.3 \pm 0.2 \mathrm{kPa} ; 2.3$ $\pm 1.6 \mathrm{~mm} \mathrm{Hg}$ ). In hypoxaemia (right) the alterations

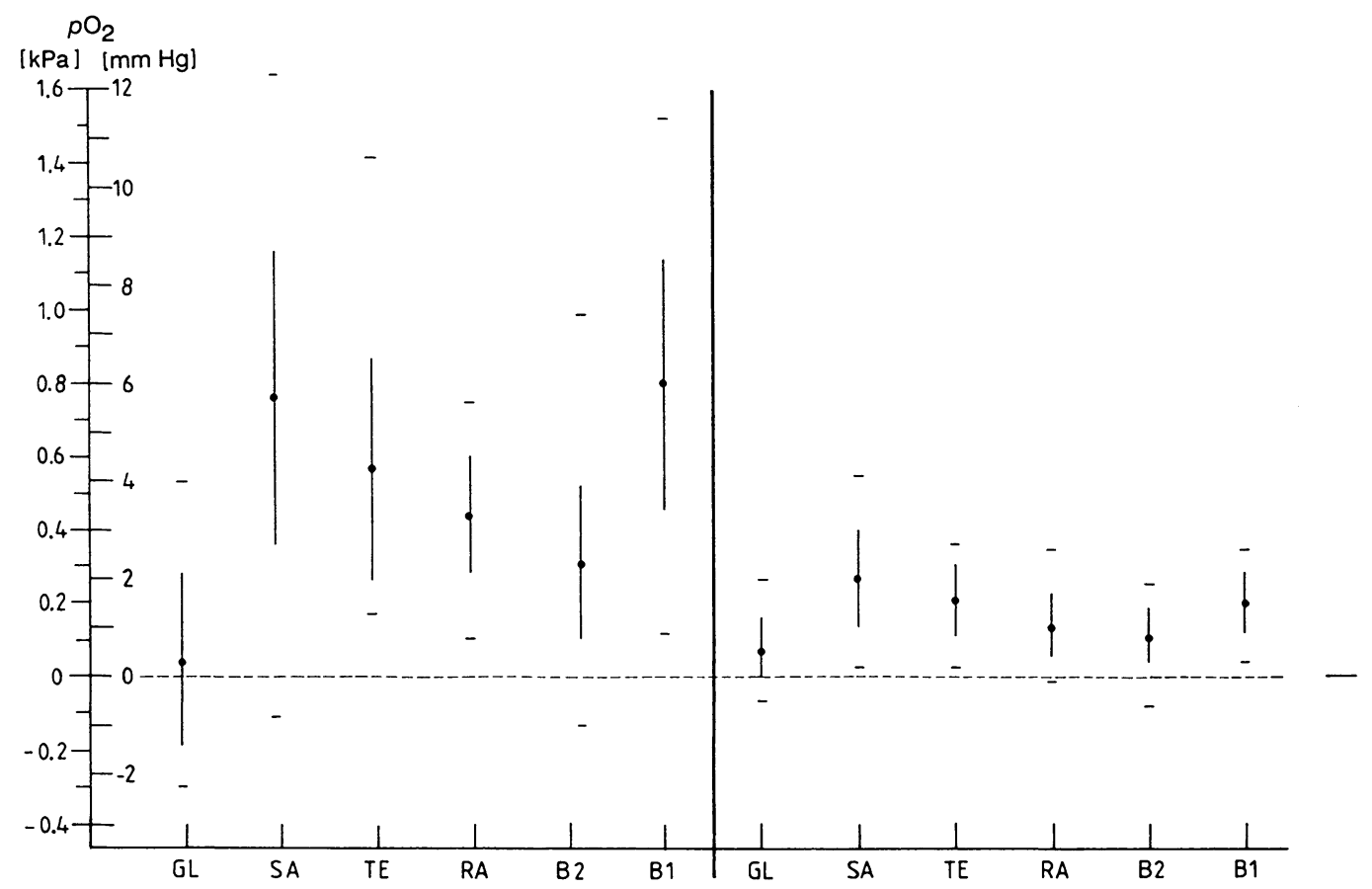

Fig. 1. Alterations of $p \mathrm{O}_{2}$ in 6 types of syringes (mean, $\mathrm{SD}$ and ranges) after 45 min storage in ice-water. Left: Normal arterial range $(\mathrm{n}=34 ; \overline{\mathrm{x}}=88 \mathrm{~mm} \mathrm{Hg} \hat{=} 12 \mathrm{kPa})$; right: Hypoxaemic range $(\mathrm{n}=25 ; \overline{\mathrm{x}}=53 \mathrm{~mm} \mathrm{Hg} \hat{=} 7.1 \mathrm{kPa}) . \mathrm{n}=$ number of measurements in each type of syringe. Symbols of the syringes (abscissa) see table 1.

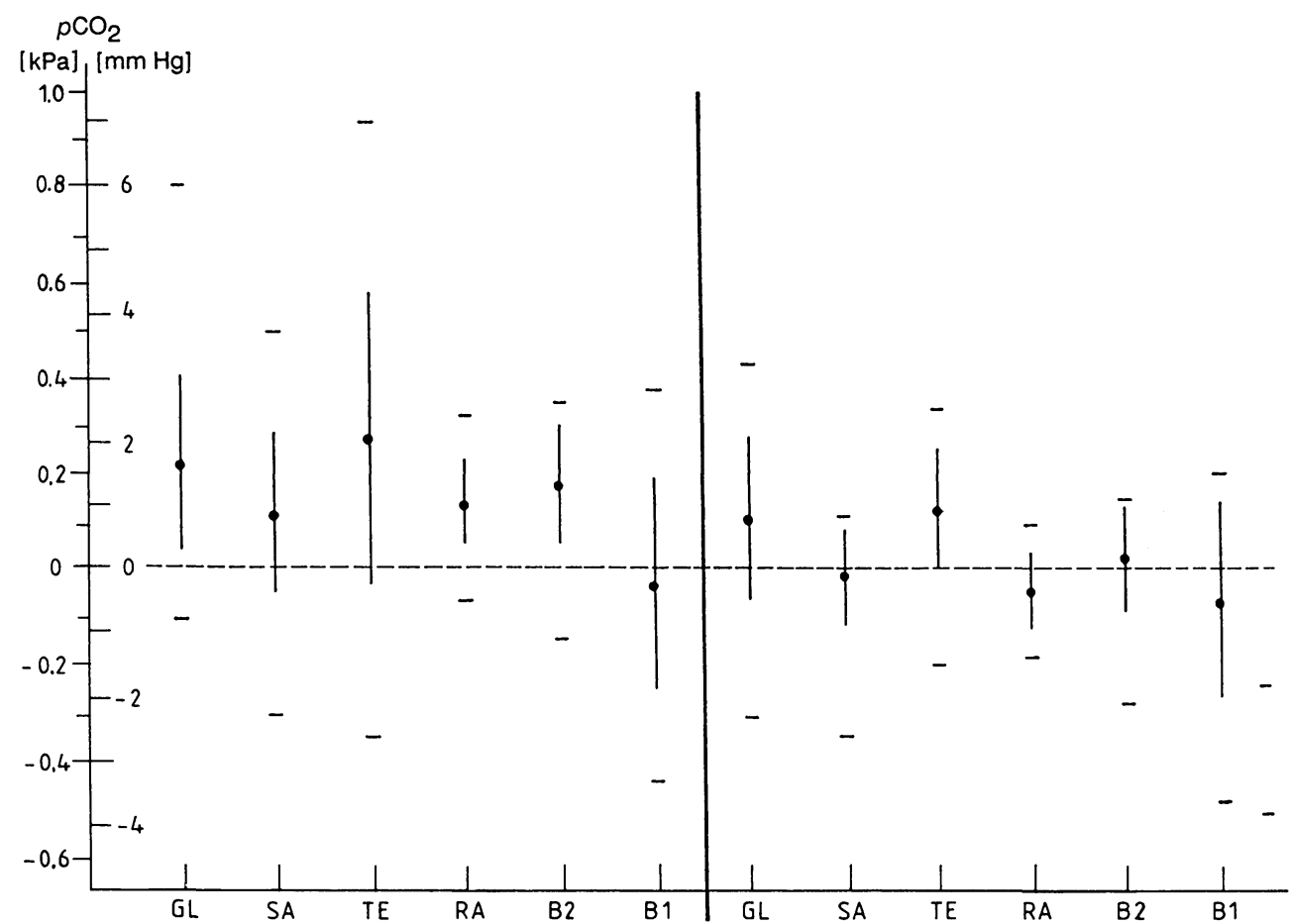

Fig. 2. Alterations of $p \mathrm{CO}_{2}$ in 6 types of syringes (mean, $\mathrm{SD}$ and ranges) after $45 \mathrm{~min}$ storage in ice-water. Left: Normokapnic range $(\mathrm{n}=34 ; \overline{\mathrm{x}}=37 \mathrm{~mm} \mathrm{Hg} \hat{=} 4.9 \mathrm{kPa}) ;$ right: Hyperkapnic range $(\mathrm{n}=25 ; \overline{\mathrm{x}}=48 \mathrm{~mm} \mathrm{Hg} \hat{=} 6.4 \mathrm{kPa}) . \mathrm{n}=$ number of measurements in each type of syringe. Symbols of the syringes (abscissa) see table 1. 


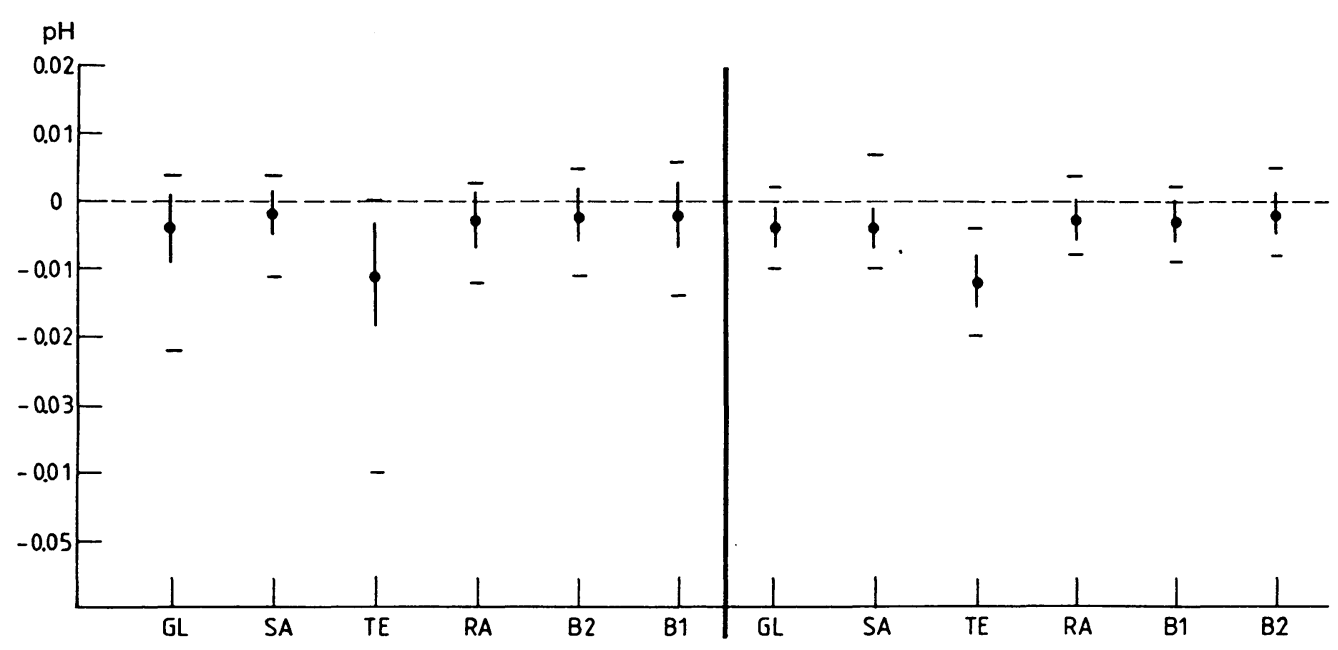

Fig. 3. Alterations of $\mathrm{pH}$ in 6 types of syringes (mean, $\mathrm{SD}$ and ranges) after $45 \mathrm{~min}$ storage in ice-water. Left: Series $\mathrm{I}$ ( $\mathrm{n}=34$, $\left.p \mathrm{CO}_{2}=37 \mathrm{~mm} \mathrm{Hg} \cong 4.9 \mathrm{kPa}\right)$; right: Series II $\left(\mathrm{n}=25 ; p \mathrm{CO}_{2}=48 \mathrm{~mm} \mathrm{Hg} \hat{=} 6.4 \mathrm{kPa}\right) . \mathrm{n}=$ number of measurements in each type of syringe. Symbols of the syringes (abscissa) see table 1.

were generally smaller, but the relation between the syringes followed the same pattern as in normoxaemia.

$p \mathrm{CO}_{2}$

At the normal level (fig. 2, left), mean increases of about $0.13-0.26 \mathrm{kPa}(1-2 \mathrm{~mm} \mathrm{Hg})$ were found, with the exception of the B1 syringe where the alteration was close to zero. The highest increase with a considerable variation was found in the Terumo syringe (TE). At the hyperkapnic level (fig. 2, right) the increases were very small or even absent.

\section{$\mathrm{pH}$}

There was a general tendency to slightly lower values (about 0.003) after $45 \mathrm{~min}$ (fig. 3). Only in the Terumo syringe, which showed the greatest increase in $p \mathrm{CO}_{2}$, was the decrease greater than 0.01 .

\section{Electrolytes (fig. 4)}

The mean increase in sodium concentration was about $1 \mathrm{mmol} / \mathrm{l}$. Potassium generally increased by about 0.1 $\mathrm{mmol} / \mathrm{l}$. In the Radiometer syringe (RA), however, $\mathrm{K}^{+}$increased by about $0.4 \mathrm{mmol} / \mathrm{l}$. Alterations in ionized calcium were hardly detectable for the Sarstedt and the Radiometer syringes as well as the syringes prepared with fluid heparin. For the Terumo syringe a fall of $0.05 \mathrm{mmol} / \mathrm{l}$ was found, which equals one third of the reference interval of ionized calcium.

\section{Haemoglobin (fig. 4)}

The mean alterations were within +4 and $-2 \mathrm{~g} / 1$ and may be tolerable for emergency situations. More

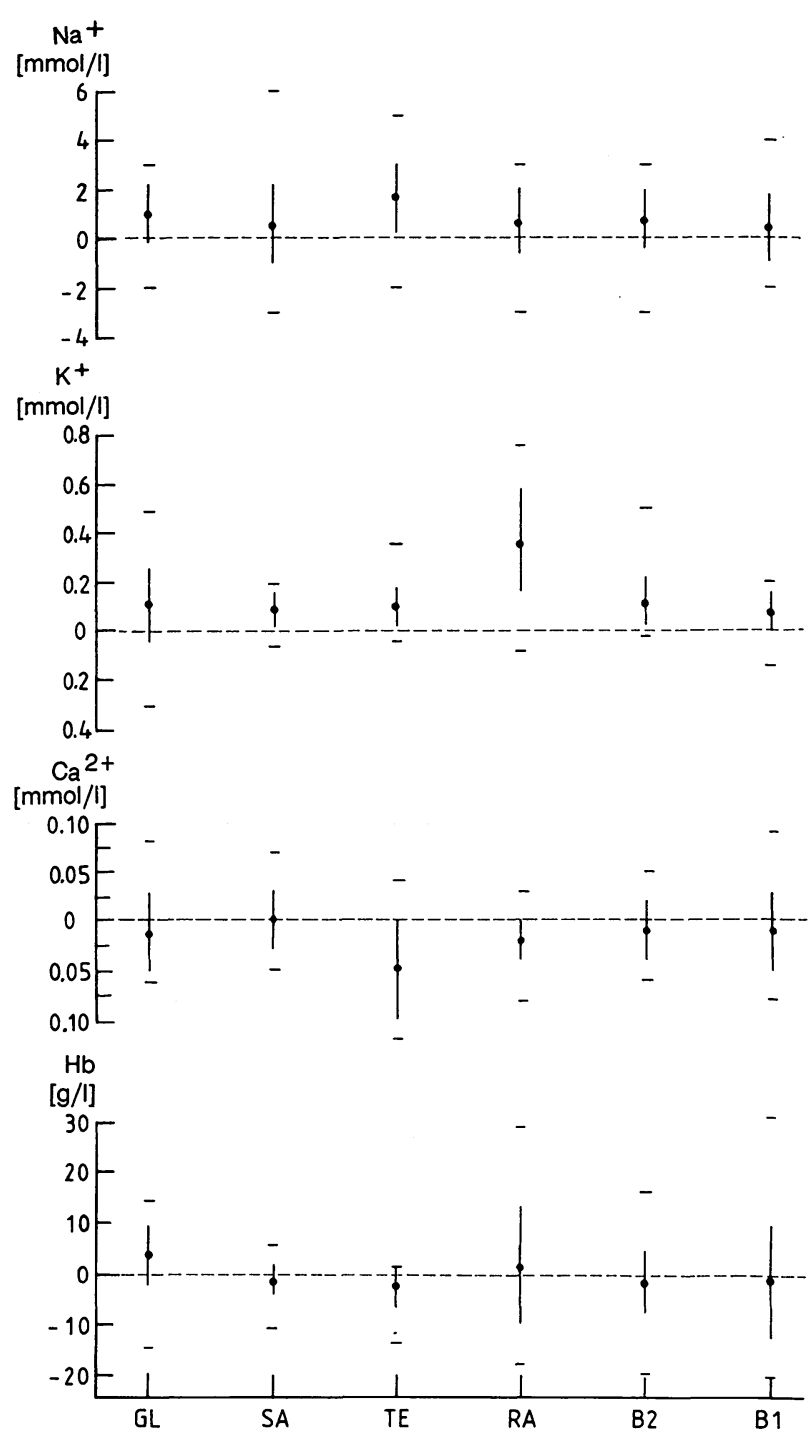

Fig. 4. Alterations of sodium, potassium, ionized calcium and haemoglobin in 6 types of syringes (mean, SD and ranges; $n=34 \pm 1$ ) after 45 min storage in ice-water. $\mathrm{n}=$ number of measurements in each type of syringe. Symbols of the syringes (abscissa) see table 1 . 
important is the poor reproducibility, which is most apparent for the Radiometer and the 1-ml Braun syringe.

\section{Series III}

Figure 5 demonstrates the alterations of $\mathrm{pO}_{2}$ in short intervals, comparing the most unfavourable syringe (1-ml Braun) with the glass syringe (GL): hardly detectable changes in the GL, a very small increase in B1 after $10 \mathrm{~min}$, but a mean rise of $0.67 \mathrm{kPa}(5.0 \mathrm{~mm}$ $\mathrm{Hg}$ ) after $20 \mathrm{~min}$ in this syringe.

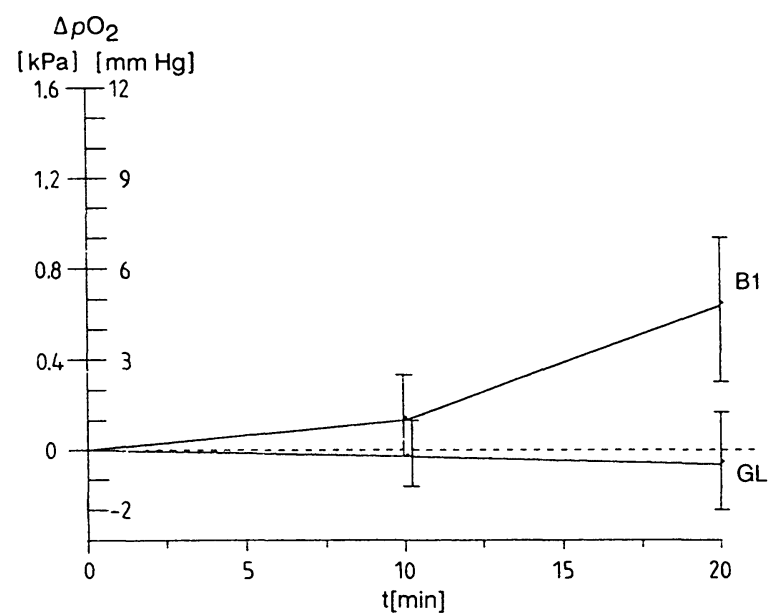

Fig. 5. Alterations of $p \mathrm{O}_{2}$ in whole blood $\left(p \mathrm{O}_{2}=85 \mathrm{~mm} \mathrm{Hg} \hat{=}\right.$ $11.3 \mathrm{kPa}$ ) in the $1 \mathrm{ml}$ syringe (B1) and in the glass syringe (GL) after 10 and $20 \mathrm{~min}$ storage in ice-water (mean and $\mathrm{SD}$ of 25 measurements in each type of syringe).

\section{Series IV}

It can be seen from figure 6 that the increase of $p \mathrm{O}_{2}$ in plastic syringes (B1) is much greater when plasma instead of whole blood is stored, e.g. $4.27 \mathrm{kPa}(32$ $\mathrm{mm} \mathrm{Hg}$ ) versus $0.93 \mathrm{kPa}(7 \mathrm{~mm} \mathrm{Hg})$ after $20 \mathrm{~min}$. There are no significant changes in whole blood or plasma at this time or later when stored in the glass syringe (GL).

\section{Discussion}

It has been known for at least 25 years that plastic materials are permeable to gases $(3-7)$. It is further known that the permeability of various polymers is different, e.g. polypropylene is less permeable to oxygen than polystyrol $(3-6)$. The suitability of polypropylene syringes for blood gas sampling and storage has been a subject of controversy for many years. There are many advocates of blood gas sampling with

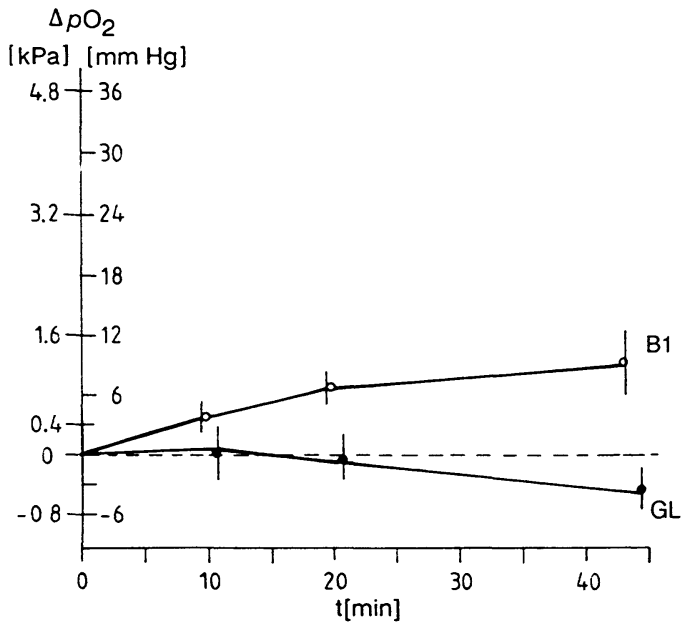

Fig. 6a. Alterations of $p \mathrm{O}_{2}$ in whole blood $\left(\mathrm{O}_{2}=85 \mathrm{~mm} \mathrm{Hg}\right.$ $\hat{\equiv} 11.3 \mathrm{kPa}$ ) stored in plastic syringe (B1) and a glass syringe (GL) during $45 \mathrm{~min}$ at room temperature (mean and SD of 15 measurements in each type of syringe).

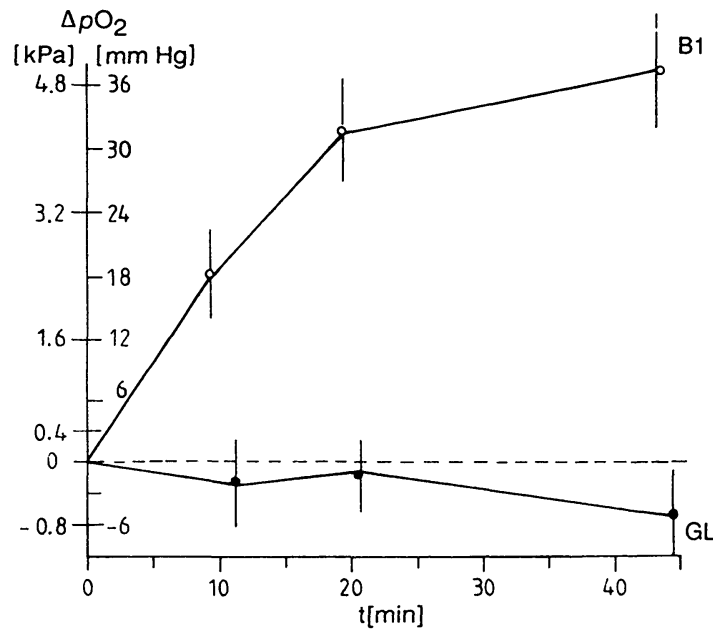

Fig. 6b. Alterations of $p \mathrm{O}_{2}$ in plasma $\left(p \mathrm{O}_{2}=85 \mathrm{~mm} \mathrm{Hg} \hat{=}\right.$ $11.3 \mathrm{kPa}$ ) stored in a plastic syringe (B1) and a glass syringe (GL) during $45 \mathrm{~min}$ at room temperature (mean and SD of 15 measurements in each type of syringe).

these syringes $(4,8-10)$, while others are critical of this kind of procedure $(5-7,11-13)$.

Against this background we strongly feel the need to examine the stability of blood gases, especially $p \mathrm{O}_{2}$, under strictly defined experimental conditions (e.g. tonometry at different levels of $p \mathrm{O}_{2}$, comparison of each measurement with results from the glass syringe as a "reference sampler", inclusion of several types of plastic syringes).

With regard to $\mathrm{pO}_{2}$ (fig. 1), the superiority of the glass syringes kept in ice-water was fully confirmed. The results with the plastic syringes (all of them made 
from polypropylene) were very different, obviously as a consequence of the respective construction. In the ordinary 2-ml syringe for injections (B2) the $p \mathrm{O}_{2}$ stability was better than in some of the sophisticated "blood gas syringes", and much better than in the 1ml syringe (B1) which was originally designed for insulin application, having an inner diameter of only $4.3 \mathrm{~mm}$. Thus, the volume-to-surface ratio becomes very unfavourable. Furthermore, our data show that the original $\mathrm{pO}_{2}$ level of a blood sample influences the alterations considerably (fig. 1 , right). They are much smaller in the hypoxaemic range than in the normal arterial range, in spite of the larger $p \mathrm{O}_{2}$ gradient between the blood and the surroundings. This can be explained by the presence of more deoxyhaemoglobin available for $\mathrm{O}_{2}$ binding. Deoxy-Hb serves as a kind of " $p \mathrm{O}_{2}$ buffer". When deoxy-Hb is low because $s \mathrm{O}_{2}$ is close to 1.00 , the instability of $p \mathrm{O}_{2}$ increases. When deoxy- $\mathrm{Hb}$ is absent due to removal of $\mathrm{Hb}$ (i.e. plasma), $p \mathrm{O}_{2}$ rises extremely (fig. 6b). Thus, storage of plasma instead of whole blood demonstrates the full extent to which plastic syringes are non-gas-tight.

As a practical conclusion, it can be deduced from figures 5, 6a and $6 \mathrm{~b}$ that blood stored in plastic syringes should be analysed for $p \mathrm{O}_{2}$ within 10 to 15 minutes after sampling.

No particularly new data were obtained for $p \mathrm{CO}_{2}$. In general, there was a slight increase in spite of cooling the blood. The apparent stability of $p \mathrm{CO}_{2}$ in the $\mathrm{B} 1$ seems to be the result of $\mathrm{CO}_{2}$ losses (by lack of tightness) which approximately equal the $\mathrm{CO}_{2}$ production.

\section{$p H$}

The very small decrease in $\mathrm{pH}(-0.003)$ during storage in ice-water was confirmed. The larger decrease in the Terumo syringe, which showed the highest increase in $p \mathrm{CO}_{2}$, should be clarified by the manufacturer.

\section{References}

1. Müller-Plathe, O. \& Schreiber, R. (1991) Eine elektrolytadaptierte Heparinlösung für die Bestimmung der Blutgase und der Elektrolyte im Vollblut. Anästhesiol. Intensivmed. Notf. Schmerzther. 26, 161-164.

2. Burnett, R. W., Covington, A. K., Maas, A. H. J., MüllerPlathe, O., Weisberg, H. F., Wimberley, P. D., Ziljstra, W. G., Siggaard-Andersen, O. \& Durst, R. A. (1989) IFCC method for tonometry of blood: Reference materials for $p \mathrm{CO}_{2}$ and $\mathrm{pO}_{2}$. J. Clin. Chem. Clin. Biochem. 27, $403-$ 408.

\section{Electrolytes}

The average increase in sodium of $1 \mathrm{mmol} / 1$ in all syringes is explained as a release of $\mathrm{Na}^{+}$from the wall of the container. As the sodium electrode actually measures ionized sodium only, a higher degree of dissociation after storage must be taken into consideration. But with a $\mathrm{pH}$ decrease of 0.003 a change in dissociation seems unlikely.

It is assumed that the increase in potassium of 0.1 $\mathrm{mmol} / \mathrm{l}$ is caused by release from the red cells. The $\mathrm{K}^{+}$rise in the Radiometer syringe is unexplained. It should be mentioned that this type of sampler has been replaced by a new one in the meantime (Radiometer QS 90).

Ionized calcium should not be measured in blood sampled with the Terumo device that we used in the present investigation (Preza-Pak II). This syringe is prepared with heparinate without calcium titration yielding a final concentration of $50 \cdot 10^{3} \mathrm{IU} / \mathrm{l}$. We found bias of $-0.2 \mathrm{mmol} / \mathrm{l}$ in blood from this syringe, even immediately after sampling. Together with the alteration during storage $(-0.05 \mathrm{mmol} / \mathrm{l})$ this adds up to a total bias of $-0.25 \mathrm{mmol} / \mathrm{l}$ (!). It is now the general consensus that - if a determination of ionized calcium is intended - calcium-titrated heparin must be used when the final heparin concentration after filling the syringe exceeds $15 \cdot 10^{3} \mathrm{IU} / 1$ blood $(1,14)$.

\section{Haemoglobin}

The determination of haemoglobin (or haematocrit) in blood gas samples bears the risk of unacceptable imprecision, because of the difficulty of resuspending the blood cells properly (fig. 4 , bottom), and the risk of severe inaccuracy by dilution of the specimen if fluid heparin preparations are used.

Finally it must be emphasized that the ideal "blood gas-electrolyte-haemoglobin sampler" is non-existent. The authors hope that the present investigations may help to develop improved devices for sampling.

3. Lebovits, A. (1966) Permeability of polymers to gases, vapours and liquids. Mod. Plast. 43, 139-150 and 194213.

4. Evers, W., Racz, G. B. \& Levy, A. A. (1972) A comparative study of plastic (Polypropylene) and glass syringes in bloodgas analysis. Anesth. Analg. (Paris) 51, 92-97.

5. Hilty, H. \& Karendal, B. (1969) Effect of syringe material on oxygen tension in stored blood. Act Soc. Med. Ups. 74, $193-205$. 
6. Scott, P. V., Horton, J. N. \& Mapleson, W. W. (1971) Mechanism and magnitude of leakage of oxygen from blood and water samples stored in plastic syringes. Br. J. Anaesth. 43, 717-718.

7. Toda, H., Murakawa, M., Toshiyuji, A., Hatano, Y. \& Mori, K. (1987) Influence of syringe materials on arterial blood gas measurements. [In Japanese, engl. abstr.] Masui $36,694-698$.

8. Bageant, R. A. (1975) Variations in arterial blood gas measurements due to sampling techniques. Respir. Care 20 , $565-570$.

9. Nakamura, T., Sakai, Y., Miyasaka, K., Sankawa, H. \& Fujikawa, J. (1982) Clinical experience with Preza-Pak II. A pre-heparinized sampling syringe. J. Intensive Care Med. 6, 611-618.

10. Winkler, J. B., Huntington, C. G., Wells, D. E. \& Befeler, B. (1974) Influence of syringe material on arterial blood gas determinations. Chest $66,518-521$.
11. Harsten, A., Berg, B., Inerot, S. \& Muth, L. (1988) Importance of correct handling of samples for the results of blood gas analysis. Acta Anaesthesiol. Scand. 32, 365368.

12. Janis, K. M. \& Fletcher, G. (1972) Oxygen measurements in small samples. Am. Rev. Respir. Dis. 106, 914-916.

13. Restall, R. V. F., Miller, S. E., Hahn, C. E. W., Epstein, H. G. \& Foex, P. (1975) Plastic or glass syringes: A comparison of the changes when blood or water samples are stored in iced water. Br. J. Anaesth. 47, 636-637.

14. Boink, A. B. T. J., Buckley, B. M., Christiansen, T. F., Covington, A. K., Maas, A. H. J., Müller-Plathe, O., Sachs, Ch. \& Siggaard-Andersen, O. (1991) IFCC recommendation on sampling, transport and storage for the determination of the concentration of ionized calcium in whole blood, plasma and serum. Eur. J. Clin. Chem. Clin. Biochem. 29, 767-772.

Prof. Dr. O. Müller-Plathe Zentrallaboratorium

Allgemeines Krankenhaus Altona

Paul-Ehrlich-Straße 1

W-2000 Hamburg 50

Bundesrepublik Deutschland 
